\title{
Studying the Effect of Continent on Three Important Mosque of Timurid Period (Blue Mosque of Tabriz, Goharshadjame Mosque, Jame Mosque of Yazd)
}

\author{
Davoud Saremi Naeeni ${ }^{1} \&$ Kobra Hasangholinejad Yasoori ${ }^{2}$ \\ 1 Assistant professor, art and archtecture faculty, university of kharazmi, tehran, Iran and Sistan and \\ Baluchestan University, Zahedan, Iran \\ ${ }^{2}$ Phd student of architecture, univer sity of sistan and baluchestan, Zahedan, Iran \\ Correspondence: Davoud Saremi Naeeni, Assistant professor, art and archtecture faculty, University of Kharazmi, \\ tehran, Iran and Sistan and Baluchestan University, Zahedan, Iran. E-mail: dsaremi@yahoo.com/ \\ kimia.gholinejad@gmail.com
}

Received: November 25, 2015

Accepted: December 7, 2015

Online Published: January 15, 2016

doi:10.5539/mas.v10n2p205

URL: http://dx.doi.org/10.5539/mas.v10n2p205

\begin{abstract}
Mosques' architecture is one of the monuments in the history of Iranian architecture that has alwaysbeen of interest andimportance and in the Timurid period was also welcomed by many architects and artists and examples were built that were used as a perfect model for the architects of the next periods. The architecture of this period is known as a good example of harmony with the environment, which is a result of various climatic, historical, economic, cultural and political factors and have had the greatest impact and benefit fromthe continental and social and politicalconditions of Ilkhani and Seljuk periods. Timurid mosques of Iran are from the important elements of Islamic architecture in terms of architectural form and decorations that need to be reviewed in these two factors. Building mosques in Iran, as a public place and a political state for the spiritual guidance was started at the beginning of Islam and was completed in the Timurid era in the various buildings. Mosques were firstly build as Shabestani and then as one Iwan and two Iwans and four Iwans, as one of the important elements in the cities.

Given that the architectural design, construction and decorations of some of theTimurid mosques are from the architectural masterpieces of Iran, this article has considered three important mosques of the Timurid period in Iran, GoharshadJameMosque,Jame Mosque of Yazd, Blue Mosque of Tabriz, and has analyzed and compared the structural elements of the architecture of these mosques (dome, Iwan, courtyard,and use of geometry in buildings, etc.) as well as considering the climatic factors that impact on those building. The method of research is comparative study and case study and then with an analytical approach, we will compare three important mosquesin terms of political, social situations and also physics and structure and geometry and decorations of them. In addition to reviewing the related papers and books, we will have a comparative table for the physical elements and their decorations. Finally, in addition to achieving the objectives of constructing the mosques and their formal changes in this period and comparingthem, the status of each of them is reviewed in the main section of the paper and the analytical model for future studies for mosque's architecture according to the continent, is recommended.

In this research with the aim of considering the methodologies of building mosques' architecture according to the continent, first we consider the physical features of architecture in Timurid period. Then we consider the architectural physical features of The Blue Mosque of Tabriz, GoharshadJame Mosque, and Jame Mosque of Yazd as some examples. After that, the general characteristics and structural form of mosques according to the continent and the domestic architecture of the regions was analyzed. At the end, comparing the features and similarities of mosques and the differences in mosques' architecture in this period, we have found some strategies about building mosques according to the domestic and continental architectural features.
\end{abstract}

Keywords: Timurid period, mosques' architecture, continent, Blue Mosque of Tabriz, Goharshad Jame Mosque, Jame Mosque of Yazd 


\section{Introduction}

Islamic architecture of Iran is the result of the natural continuation of the architecture of different periods, and understanding and studying this architecture can help us to develop our knowledge and understanding about Islamic architecture and the various aspects of it. Unfortunately, despite this important fact, architecture of this period has not been identified and studied properly and comprehensively, and there are fundamental uncertainties about the evolution and development of this architecture, history of the buildings remained, typology, elements of the techniques, styles of architecture and the like.

Timurid architecture is in fact the continuation and development of Seljuk architecture. The architectural focus on building mosques and other buildings, alongside a wide variety of buildings with different functions and using of maps with the dominant element of the Iwan (porch), domes and apron, great ability in establishing the structures of arches and domes, use of available materials, and artistic and extensive use of decorative plaster and the like, are among the features of Iranian architecture in the Timurid period, which are discussed in this study.Timurid architecture, benefiting from Ilkhani and Seljuk and using Iranian architects and artists, gained strong and complete structure and principles, which the buildings remained from this period show these features very well; features such as orientation toward greatness, progress in a variety of decorations, growth and excellence in vaulting techniques and crisscross vaults and geometry application; Examples built in the Timurid period were welcomed by many architects and artists and were used as a perfect model for the architects of the next periods. Among the famous and important mosques in this period we can refer to Blue Mosque of Tabriz, GoharshadJame Mosque, and JameMosque of Yazd which are studied in this research as examples.

Due to common physical characteristics of the architecture of mosques in Timurid style, results indicate that the architecture of the mosques in this period have similarities with the mosques of Seljuk and Ilkhani periods in terms of function, structure and decorations. The details of each period differs from the others, but they have many similarities in terms of general principles. Also based on different physical properties ofTimurid architecture, revision of the principles used is necessary to seek appropriate solutions for the architectural designtoday, so that we can reach its special goals, which is building the structure according to the climate and maintaining it, to reachcomfortin life.

\section{Research Questions}

Has climate and weather had an impact on the formation of the elements of the mosques (Dome, Iwan, vault, ...)? How is the formation of the mosque and its structure in terms of the establishment of the building and the design of the mosque and also what are the elements associated with the formation of the mosque?

\subsection{The Historical Evolution of the Timurid Period}

At the end of the fourteenth century, due to political unrest, Iran was a good prey for the fiery ambitions of Timur Lang, who was often called by this name. Timur Lang was the leader ofone of the tribes that made it a great empire in the world. Great cities of Timuridempirein Central Asia and Afghanistan, Green city, Samarkand, Bukhara, and Herat were considered centers of art and culture and were a symbol of the greatness of the Timuridpower (Pope, 1994, 232).

At the end of the fourteenth century Iran was built according to the architectural style and building method of Seljuk period which in the shadow of the domination of Great Mongolstook on a new scale and grandeur.Similarly, the architecture of the fifteenth century, continued major architectural forms of Mongols, but with more reasonabledelicacy and skill. A period in which all kinds of art, including art of living, was manifested and reached perfection (Pope, 1994, 232-233). The first period begins from the time of Hulagu and Maraghe being the capital, and the second period begins from the time of Timurand Samarkand being the capital. It was in the second period that great architects such as Ghavamud-din Shirazi and his son, Ghiyasud-din and Zein al-AbedinShirazi, were employed in great Khorasan and built big buildings there (Pirnia, 1999, 214).

\subsection{The Role of Mosques in the Formation of the Timurid Architecture}

The mosque with its social and democratic character, replaced the magnificent palaces which announced the pride and power of kings boastfully; it gained importance like the church in medieval Europe and became an immediate center. The mosque was a politicalcentre and had influence and various central tasks. The mosque has always had spiritual and material bond with people and their lives, and it is often part of the city physically and in fact can be judged to be a center for it (Pope, 1994, 94).

The mosque's architectural vision may generally be considered an internal project that was conceived in isolation from the outside world andemphasized on its inner focus. From the characteristics of these yards is the repetition of architectural elements of Iwan and columns which gives it a kind of integration, and at the same time shows 
its goal which is the most profound kind of unity. It is in the mosque that this goal is reflected in spirit and sense of community (Pope, 1994, 95). After Islam came to Iran,a huge wave of building work emerged. In religious ceremonies, they used an open place which was separated by a ditch or some chains around that. Religious and unreligious buildings were always needed and they had to build them with the local materials and techniques. Any of the buildings which were made at the first two Islamic centuries has not remained. In this era we can divide mosques in three groups. There were three kinds of mosques, the pergola, meaning a dome over a square room (the Sasanian fire temples), the open Iwan (an arch style like TaqKasra), and the open courtyard (inscribed in the Iwan (modified Arabic)).The most significant religious monument of each city, whether it is small or big, is its Jame Mosque; the oldest mosques havealways attracted public interest (Pope, 1994, 96). These types of mosques did not have any particular political aspect. Any type of government that was established in a city,put them under its protection.Jame mosque, as a public square,was considered the best place to deliver the state's acts and decrees to the public.Some of these commands in the form of inscription stones installed in the walls of the mosque in this period, is remained now. Mosque architecture is one of the important factorsin the formation of the Timurid government (Golombek, 1995, 80-81).

\subsection{Timurid Monuments Stylistic Features}

Thinking about the style of each period as a single law influenced by many factors, is useful. These factors include many architectural aspects such as local materials, local building tradition, taste of the builder, function of the building, availability of capital, labor, and profession of the architect. Reciprocal role of these factors create a practical law (i.e.role responsible for role) (Golombek, 1995, 253).

In buildings, especially religious buildings, they have always built a dome that this dome has had special features. Buildings of the Timurid period, usually have had Iwans, which are built as semi-circles with small and large rooms. When a building was constructed, many coloumns were used with the aim to strengthen the buildings (Golombek, 1995, 286). Intense use of geometry that can be seen in the architecture of the Timurid period, was not mostlyfor the construction work, but there is a thought that makes it necessary. The topic and idea of geometry in terms of dimensions and exemplifications and decorations, is seen in thevaulting style and setting out the space. Consider the outside space of a Timurid building; the shapes are strongly geometric; up to the fifteenth century,there were few buildings in Iran, except tomb towers, in which the aim of the construction isbeing completely visible from the outside. Geometric design and building and decoration of the space, are among the factors that create the unifying power of Timuridarchitecture.In Timurid architecture, geometry is not just a means of achieving the goal, but it is the goal itself. In fact it is one of the main underlying themes of aesthetic principles. The building shall not have only ageometric framework, but it shall seem geometric in the final analysis. Geometry is a major subject for the architecture, as it is for the decoration too (Golombek, 1995, 289).

\subsection{Physical Features of Architectural Elements and Decorations in the Timurid Period}

Temporal features were very useful in this style. At that time they needed to build various buildings which should have been ready as soon as possible. So, the construction process was accelerated and after that, they started "PeymoonBandi" and using the same elements like "Karbandi" in the structure and the array (Pirnia, 2008, 214).

If we look at the spatial construction, decoration, or other aspects of the building, it reveals that there are more than one Timurid style. Thinking about the style of each period as a single law influenced by many factors, is useful. These factors include many architectural aspects such as local materials, local building tradition, taste of the builder, function of the building, availability of capital, labor, and profession of the architect (Golombek, 1995, 253). The main process of the Timurid Law, as the style of the Timurid Empire, is identified and efforts will be made to identify factors that have contributed to the emergence of that.This style, firstly under the influence of a group of architects of Shiraz between 1410 and 1445was rapidly transformed to the Timurid style (Golombek, 1995, 254).One of the other features of this architectural style is using more of geometry in the design of the architecture; and for this reason the variety of tresses in this style is more than others.Also in this style, very big buildings were built that were unique and were not built in the past, such as Soltanieh Dome and Alishah Mosque of Tabriz which had majestic sizes. They also took advantage of triangular system of vaulting and the most important crisscross vaulting system on the rectangular spaces.All kinds of maps with a Miansara (middle yard), with four Iwans, were used for mosques and schools. Tombs were extrovert like the past, and were built mostly with an undertone in four corners specially in the second period; and most of them are foursquare and have double-shell discrete Nari domes (Pirnia, 1999, 214). Characteristics of Timurid architecture penetrated in the remotest regions in the west of Islamic world, and the innovations of Timurid architecture were 
transferred to the west so that the Timurid style became an international one.The importance of Timurid architecture is not only in the magnificent imarets of Central Asia, but also in the inspiration and enthusiasm it created in theterritories of the Islamic East, from Turkey to India.The style and structure ofTimurid architecture was propagated through the direct recognition of the imarets, maps, and their designs, and migration of architects and professionals.A chain of artistic resources and talents in Timuridthrones created the possibility of stablishingthe royal style of architecture and the next imperial powers such as Safavids, Ottomans and Indian Timurids, not only took advantage of the shapes and patterns of Timurids, but also they used the Timurid ideals wherever possible (Blair, 1999, 254).

One of the most important aspects of the Timurid architecture, has been to transfer the enthusiasm of the builders, which is seen in so many literary resources. This enthusiasm had not aimed to create beauty, but it aimed to create that kind of glory and grandeur that can reflect the power of the dynasty. The scale and the trappings were two major features to reflect the magnificence and grandeur of the builder; in this architectural style, geometry was mostly used in the design (Golombek, 1995, 277).

If we want to enumerate the Timurid monuments in terms of their artistic importance, strength and reputation respectively, then mosques are on the first place, and after that there are schools, monasteries, shrines, and etc.Timurid architecture, benefiting from Ilkhani and Seljuk and using Iranian architects and artists, gained strong and complete structure and principles, which the buildings remained from this period show these features very well; features such as orientation toward greatness, progress in a variety of decorations, growth and excellence in vaulting techniques and crisscross vaults. The mosque is one of the buildings that has always been important and noteworthy during the history of Iranian architecture, and also in the Timurid period it was welcomed by many architects and artists. The art of corner building and transition from square to round, has continued since Seljuk till Timurid period, and has completed in the other periods (Blair, 1999, 254).

Undoubtedly, the symbolic aspects of architecture and decorations of the historical monuments is very important. Research and study about these monuments is an undeniable necessity for thinkers of the architectural history of the country, since these monuments in each period are representative of some secrets, which understanding them can lead us to the recognition of the architects. These secrets are reflected in the form of symbols in different geometric, vegetable, arabesque, and inscription shapes. The Timurid period is one of the important periods in the history of this land (Golombek, 1995, 276).

\subsubsection{The Method of Building Domes in the Timurid Period Architecture}

The dome is one of the important elements in the Iranian architecture and one of its impartible sections. The reasons for the use of dome in the architecture was that Iranians primarily did not like buildings with so many columns and they used the methods of building the dome, so that they can create a big space without any columns. Timurid architects preferred to build a dome to cover the indoor space, large or small; they usually built the domes with inclined rows which formed concentric rings. The Gypsum mortar stiffened soon and they could build the dome without formatting. The domes which are over the vast spaces, have a significant thickness in their tholobate. This thickness of the tholobate is in order for the disposal of the dome's thrust through creating weight. Therefore as the dome goes upper, the thickness reduces, so that at the top of the dome, its thickness reaches to the last two or three rows. At this period, common domes had been single dome, double dome, triple dome, and hovel dome (Golombek, 1995, 157-158).

The main technique of building the dome in the Azerbaijani method of architecture in theTimurid period is in the form of double-shelldiscrete Nari domes. In this method, many of these domes were built, because in addition to covering the building, it was a response to the formal and symbolic aspect too. Many of the buildings of big Khorasan have this kind of dome (Pirnia, 2008, 217). In this method, in order to build the discrete dome over the parietal, some walls were built named "Khashkhashi" that the dome itself was mounted on them. The drum was built in two kinds, tholobate and "Erbane". Albeit the continuous double-shell domes were also used in buildings. In this period, several kinds of vaults were used such as wagon vault, Colonboovault, and ribbed vault. Karbandi was also used very much in order to fill inside the ribs. Generally, Karbandi and Peymoon in spaces in this method have been used in order to create consistent and uniform parts in the buildings and in the coverage for the areas which have had different sizes (Pirnia, 2001, 219).

\subsubsection{Arrays and Decorations in Timurid Architecture}

Decorations in the idea and culture of many people, is the most prepared sign of identification of Islamic architecture. Forms also can have this cognitive feature, but less clearly. Some of the forms are essentially Islamic in nature, such as Mogharnas with all of its kinds; albeit Islamic architects commonly and with satisfaction used available forms appropriate to the climate, in the culture of their ancestors in order to reach 
their goals. In the Timurid architecture there was no new topic. In this period, vegetative decorations with abstract motifs and calligraphy could be seen (Golombek, 1995, 172).Mosques were stiffened hastilywith adobe brick, or brick and rubble or picked stone, without face stone. Then it was exterior finished which was done with a pellicle of brick, brick node, or stucco, and then it was painted. Sometimes brick node with tile and interlocking node ("Maghali") were used for the exterior finish. Little by little using of bricks was reduced and tile (glazed clay) and fresco clay with embossed fresco ("Mohri") were replaced. One of the other kinds of Amood was mosaic work which progressed in this period very much; also using seven-colored tile and adobe tile was common in some buildings. Some of the Khorasan buildings that were destroyed, after the fresh dinging with plaster, were furrowed and built it like brick work (Golombek, 1995, 216-218).

Timurid architecture design principles had a very close relationship with geometric decoration (Golombek, 1995, 218). InTimurid architecture, decoration has a prominent role in increasing the effectiveness of the building. Timurid decorativecoverings, have shining colors and various bosses, therefore because of changes in the refraction and decomposition of light, which is a result of variety of materials, namely glazed and unglazed tile and stone, they are appreciable. Surely decoration in Timurid architecture have had a broader purpose than its function in the Western architecture. While some types of decorarions inTimuridmonuments, highlights the architectural lines, some of the others add to the general sensing of the monument (Golombek, 1995, 218).

\subsection{Geographic Factors and the Impact of Continentalschemes}

Various and vast climatic characteristics of the Muslim world have also had a similar impact on Islamic architecture. The influence of desert and salt pan and their heat, rare rainfall and water shortages can be seen in many large mosques. It is completely right that the mosques were corrected in time, in order to consider various climates, tastes, and functions (Brand, 1998, 60).

Exaggeration about the role of geographical factors in the development of Islamic architecture is difficult. In a pleasant symmetry, the effective factors of Islam in some of the Timurid monuments have been specifiedwhich we have discussed. In each village, the green color of tiles with trees and streams in their background, blazon the village. Ordinarily there was no attempt to cover the relationship between such decorations with the concepts of growth, abundance and fertility, which was not without a reason. The art of architecture is greatly under the influence of geographic and climatic factors. As we can see, the buildings which are built at the mountain areas and highlands and beaches and moist, forestialareas,are essentially different from the buildings of the warm and dry areas; even the type of the materials which is used in buildings, is available in the nature of each area (Brand, 1998, 58).

\subsubsection{The Impact of Continent on the Physical Spatial Formation of the Mosques}

An important point about the building of the mosque is that the physical body of the mosque in buildings around the world, has a series of specific characteristics such as the establishment in Mecca side and not in the sun side or wind exposure, the establishment of the mosque toward Mecca as the center of attention and often on the main axis of the mosque, together with the symmetry in plan and section, and separation of the interior space of the mosque from the outside environment, especially in terms of view.Jame mosques, in terms of urban, ethnic, or political identity are often among the highest and the most beautiful and in some cases the largest buildings in the city (Qobadian, 2003, 208-254).

So the continental conditions could not be very essentially influential in the shape and placement of the mosques like the other buildings. Many other factors, mostly religious or political and historical, were more important than the continental conditions, in the designing of the mosque building. Albeit it is worth noting that also in the context of these religious and sometimes political criteria, in the four different climates of Iran, the physic of the mosque has been adapted to the climate of each region as much as possible, in order to provide the comfort of people inside the mosque (Qobadian, 2003, 208-254). Innovation and pace of building architecture in the Timurid monuments, including mosques, represents a massive evolution of architecture, minarets and extensive decorations of this period of art and architectural history of this land. What is agreed by all researchers is that the Timurid mosques are the greatest masterpiece of this tradition (Golombek, 1995, 254). Three of these mosques in terms of importance according to the factors mentioned below are: the Blue Mosque of Tabriz, GoharshadJame Mosque, and Jame Mosque of Yazd; here we discuss their features of design, decorations, and architectural form and physics according to the continental and social conditions.

\subsection{The Blue Mosque of Tabriz}

The Blue Mosque or Shrine of Tabriz or Mozaffarieh Imaret of Tabriz, is one of the unique monuments of Islamic architecture in the QaraQoyunlus period. This monument is built at the end of the magnificent period of 
Timurids and has a very innovative architecture and greatand refreshing decorations. This Imaret is completely covered with azure and turquoise tiles (Golombek, 1995, 581). These are tiles with the color of the sea and sky, and amid these turquoise tiles, there are the tiles with the colors of black and white, which are arranged side by side with the style of Moarragh, in an eye-catching order. The Blue Mosque of Tabriz, because of its beautiful white, turquoise, and azure tiles which are built with the consummate mastery and precision is well known by the name of the Turquoise of Islam (Golombek, 1995, 583-584). The main door head of the mosque, with Moarragh tilling and inscriptions with "Sols" calligraphy and boards in Kufic language including Suras from Qoran, is one of the most complete Moarraghs of the Islamic periods. The inscriptions of the door head is the handwriting of Ne'matollah al-Bavab, the well known calligrapher of the ninth century, and the building's supervisor had been Ghaza al-din ben Ghapuchi. At the mausoleum part of the building, the artist has used azure hexagonal tiles for decoration.In this mosque, in addition to the simple and ungyrose construction of the dome, some types of subtle ornamental arts have been used. Moarragh bricks and tiles,embossed inscription, and different kinds of Karbandi, which all of them have such a beauty that one should only look at them with the eye of his heart, like listening to a pleasant melody in complete silence (Pirnia, 2001, 267) (Figure 1).
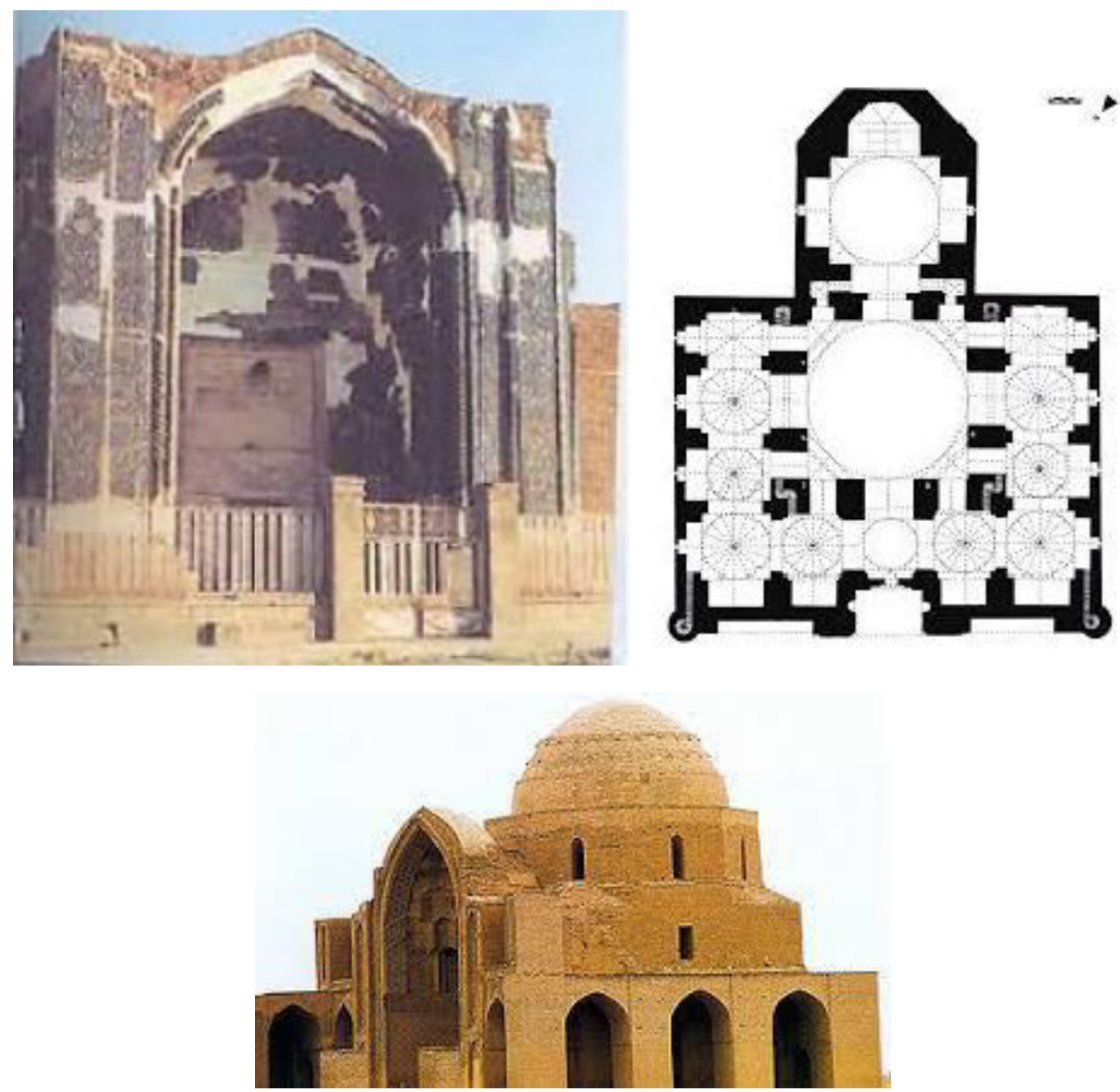

Figure 1. Face and plan of the Blue Mosque of Tabriz (pope, 1994, 245-246)

\subsubsection{Architectural Features}

Very high thermal mass of the building which is a continental advantage, is the result of the thick bases for the tolerance of heavy brick domes of the mosque. The Blue Mosque of Tabriz has no central courtyard. This mosque has been constructed at the time of QaraQoyunluJahanShah and is one of the masterpieces ofarchitecture and tiling art, which unfortunately has severely damaged by earthquakes, but the remains of the mosque still represents the high accuracy and precision which has been used in its building. The Blue Mosque of Tabriz has no Miansara (Golombek, 1995, 582).

\subsubsection{Vault and Dome}

The massive dome of the mosque, is one of the greatest brick buildings of the architects of the Ilkhaniperiod. The weight of the dome is divided on its numerous bases which are well seen from inside the mosque. The ceiling 
and the main tholos of the mosque were destroyed by an earthquake which shook Tabriz at 1193 . The form of the dome of the Blue Mosque, was built by the mighty contemporary architect, Reza MemaranTabrizi, as a continuous hollow double-shell dome with a parietal with home hasp (Chefd) which itself is built on the tholos with a harsh Shabdari hasp. The angle building of the dome is simple and has only one pendentive, which an $\mathrm{R}$ tholobate is built on that and then the dome has started (Pirnia, 2001, 254).

\subsubsection{Building Techniques and Decoration}

This mosque is known in Iran as Islam turquoise and this reputation is because of great abundance of and decoration withMoarragh tiles which most of them are in blue color. The colors of Moarragh tiles which can be found throughout the building, includes blue, white, green, yellow, and brown. These colors are used on the surface of the walls of the doorway and its semidome and on the molded simple side corners that are seen at the corners of the doorway, and on the side drawings which are executed semi embossed. Seven colored tiles are used as molded at the corners of the entrance doorway. Broad areas including the central tholos are covered with blue hexagonal tiles. In any part of the Islamic world, there has not aroused such anelegance and grandeur together in one place. In terms of design and decoration, this historical monument has a very close relationship with Shah Mosque of Mashhad, which these are two unique monuments in Iran. The physical form of this mosque is very similar to the Ottoman mosques which are under the influence of Byzantine style of Asia Minor, with a central dome and some smaller domes. This Mosque (Blue Mosque of Tabriz) with fully enclosed spaces and brickwork and thick body, is somewhat adequate for the cold climate of Tabriz. Since very high thermal mass of the mosque during the summer, allows the ventilation and vertical movement of air and cooling the inside space of the mosque through opening the upper windows (Golombek, 1995, 583-584) (Figure 2).
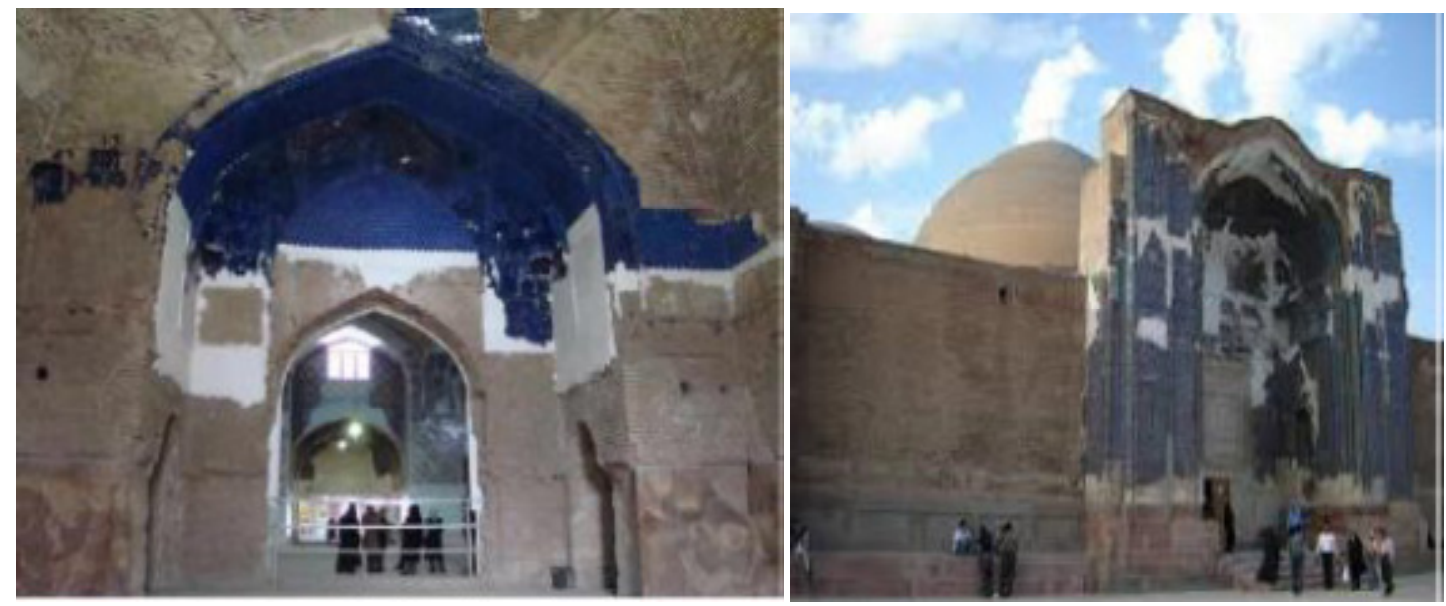

Figure 2. The Blue Mosque of Tabriz (Pirnia, 2001, 267)

\subsection{Goharshad Jame Mosque}

GoharshadJame Mosque of Mashhad is one of the well known mosques of Iran and Islamic world and a valuable and lasting legacy of Timuridart and architecture. The construction process of the building was started thanks to Goharshad, wife of Shahrokh the son of TimurGoorakani. Building of GoharshadJame Mosque was done by the famous architect of Timurid era, Ghavammoddin ben Zeyn al-Din Shirazi and using brick and plasterand with Islamic architectural style of the East (Golombek, 1995, 254). The first and the largest remaining historical monument of Iranfrom the fifteenth century, is the beautifulGoharshad mosque, near the shrine of Imam Reza in Mashhad. Its door head is the continuance of the Samarqandi arcading style, which is decorated with some recesses and corbellings that gives it power and depth. The thick tower-like minarets, that are located near the exterior corners of frontispiece, are continued to earth, and together with the long marble cover of the base of the monument,gives it a sturdy appearance, which is necessary to preserve its brilliant color. Goharshad Mosque consists of a courtyard, four Iwans, and a turquoise dome and two beautiful minarets and seven Shabestans, and because of historical antiquity, architectural style and artistic beauty, is one of the most important sites in Mashhad and in the architectural industry of Islamic Iran (Sadri Afshar, 1994, 198) (Figure. 3). 

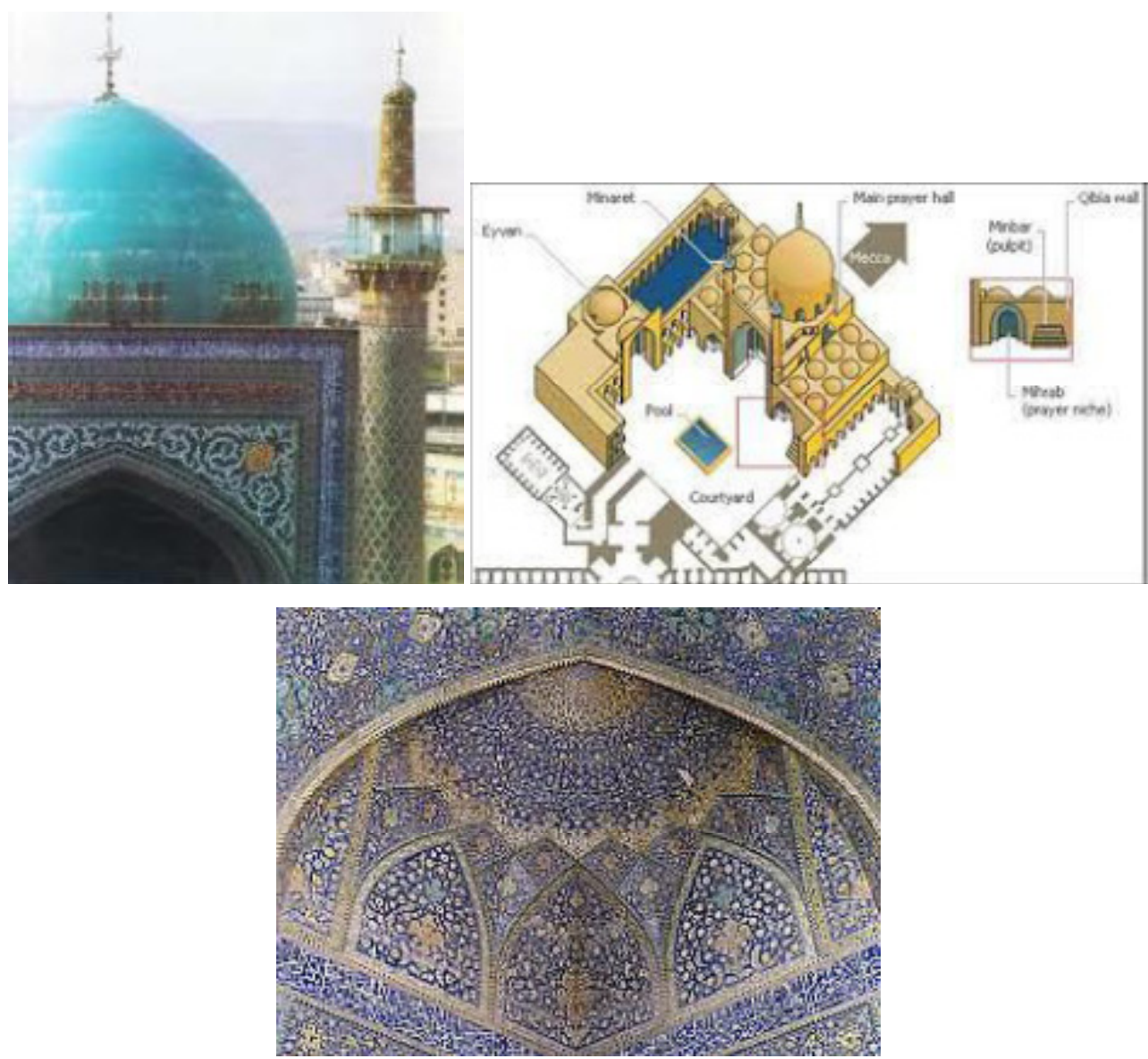

Figure 3. GoharshadJame Mosque

\subsubsection{Architectural Space Features}

This mosque has a modified four-Iwans design, which these modifications are the result of the conditions and location of the buildings. This mosque has a four-IwansMiansara. A large part of its tholos and Iwan has been rebuilt completely in the current decades, and has been built again by concrete. The shallow northeast Iwan is known as Simple Iwan. The back part of this Iwan goes to Dar osSiade. The southeast Iwan is Iwan of Haji Hasan; the Iwan located at northwest is Water Iwan, while the MaghsooreIwan is still called MaghsooreIwan. One's attention becomes focused on the MaghsooreIwan and its side minarets which have rose from the floor. In the second floor, we can see decorative enclosed Revaghs that there is a decorated wall over them which is about two meters higher than the highest double floored buildings of the southeast and northwest (Golombek, 1995, 459).

\subsubsection{Vault and Dome}

The dome of Goharshad Mosque is double-shell discrete Nari dome (Onion dome). The exterior and interior shell of the dome of Goharshad Mosque areabout ten meters apart. The distance between two shells is connected to each other by walls naming Khashkhashi. The tholobate of the dome has a less height than the other domes of Timurid period. Here, the sequence of the exterior shell of the dome is tilted from Pakar to the inside and then is placed over the Khashkhashi and tholobate, which is named Avgoon. The exterior shell of the domes such as Goharshad Mosque is called Avgoone. The interior shell of the dome is built like a skullcap and its corner building is done with long thriangles and Karbandi. one of the aspectsof the tholos, worthy of attention is the three rows of archesof the side walls on top of the spouts, which have a way to the Shabestans. While some of these rows are linked to the outer free spouts, probably there had been multiple goals for building them: beauty, lighter side walls and bringing more light into the space of tholos (Pope, 1994, 238).

From four Iwans, three of them have decorated wagon vaults, while the vaulting system of MaghsooreIwan is complex. This foreground vault has a strip of wagon vault over itself which has three meters depth. Following 
this part, there is a strip of five meters depth which is one meter narrower than the top of the walls. Then at the spout of the Iwan, it gains its width again and over this part, a big dome is raised from the series of stipuloid arches. The minarets of Goharshad Mosque which are located as twins at the two sides of MaghsooreIwan, are one of the other ways of emphasizing the Mihrab (Golombek, 1995, 459-460).

\subsubsection{Building Methods and Decorations}

All over the courtyard is covered with the best kind of glazed brick and Moarragh tiles. The most used colors are azure and turquoise blue, white, transparent green, yellow, saffron, pine and ebony black, which the tonality of each of the colors is changed to different shadows. Light and powerful inscriptions are adjusted with their decorative role; in the wall frames or in the dome ornamentation which is intended to prevent the distance of one hundred steps. A monotony that avoiding fromit in such a huge area is difficult, and a confusing complexity that may compete with the original architectural forms; both of these have been prevented, and this work has been done with the power of plants and flowers of tiling, brick work geometrical plans, and the emphasized rhythm of the Revaghs, open catacombs, and deep recesses; specially with the dramatic conflict of Iwans. The Iwan of the Shabestan is completely white, while in the other three Iwans the background of the vault is an opaque red, with light turquoise Kufic inscriptions with a white shadow which is seen as green in the red background. All decorations arecombined with unusual amounts of white color which gives it clarity and excitement. The architect had been Ghavamad-dinShiraziwho is the builder of several monuments in Shahrokhera (Sadri Afshar, 1994, 198) (Figure 4).
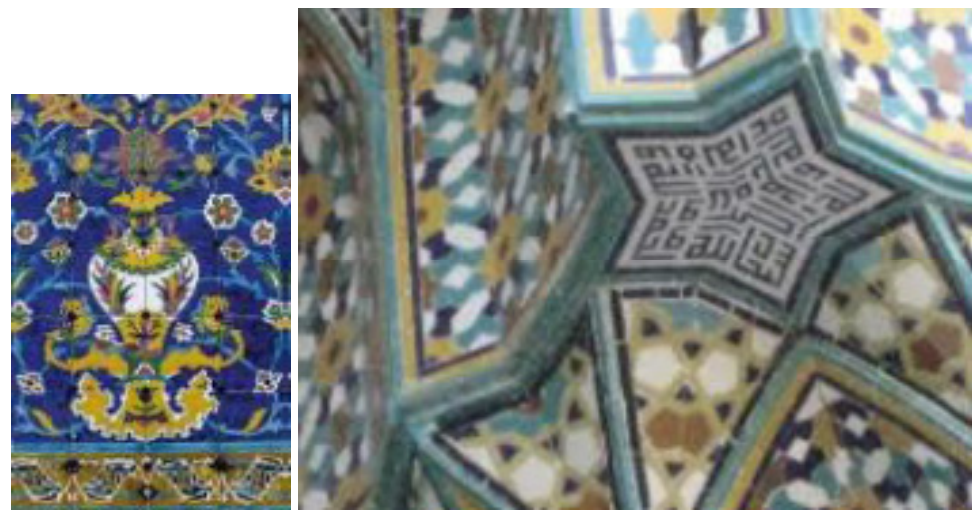

Figure 4. Decorations of Goharshad Mosque (pope, 1998, 164).

\section{8 Jame Mosque of Yazd}

Jame mosque of Yazd is one of the most precious historical heritages of art and a treasure of Islamic architecture located in the city of Yazd. This mosque consists of a rectangular courtyard of $99 * 104$ meters with a dome and Iwan at the Mecca side, which there are high Shabestans at its two sides. The southern Shabestan is linked to an embowed catacomb which is located at the back of the main door. This door head which has been repaired many times in recent years, has modified proportions which are from the characteristics of the late fourteenth century and a pair of minarets is located at the upper part of it (Golombek, 1995, 495) (Figure 5).

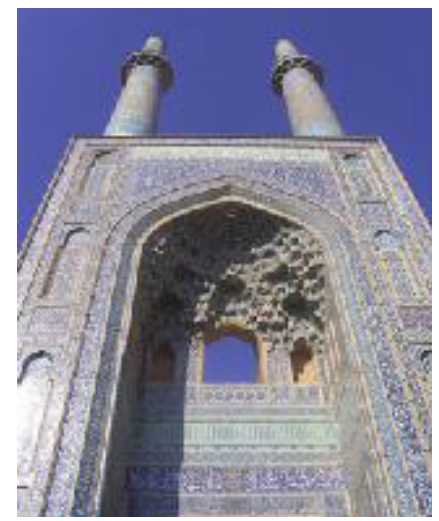



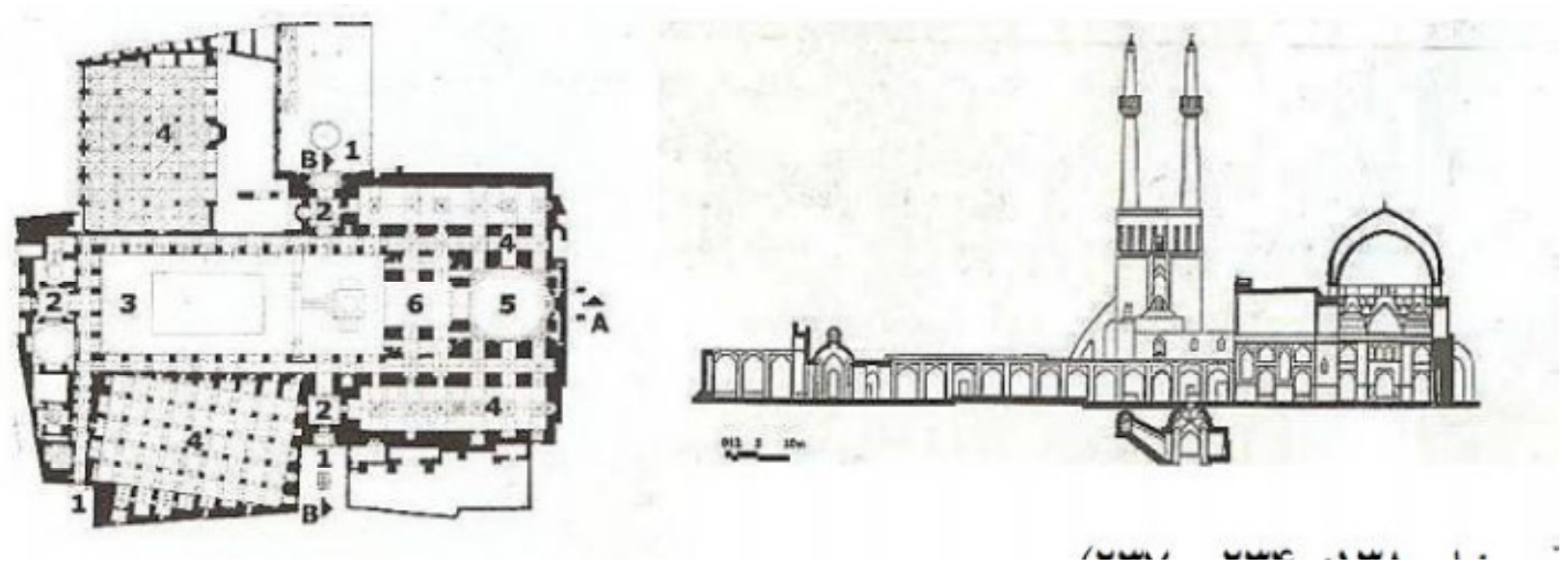

Figure 5. Jame Mosque of Yazd

\subsubsection{Architectural Space Features}

This mosque is the oldest example of that design consisting of a summery vaultyMaghsoore, and a high rectangular Shabestan or mostly called wintery mosque. The second important feature is the extensive application of all round vaults (vault and rib) in the rectangular Shabestans. The third feature is the eye-catching glazed tile decoration (Golombek, 1995, 594).

The main square-shaped tholos, has one open central spout towards the Iwan and two passwaystowardsiwan's screws that some loges were built on them later.The main side walls of the tholos have also central wide spouts which there are smaller spouts aside them, but the size of the central spouts have been reduced (Golombek, 1995, 595).
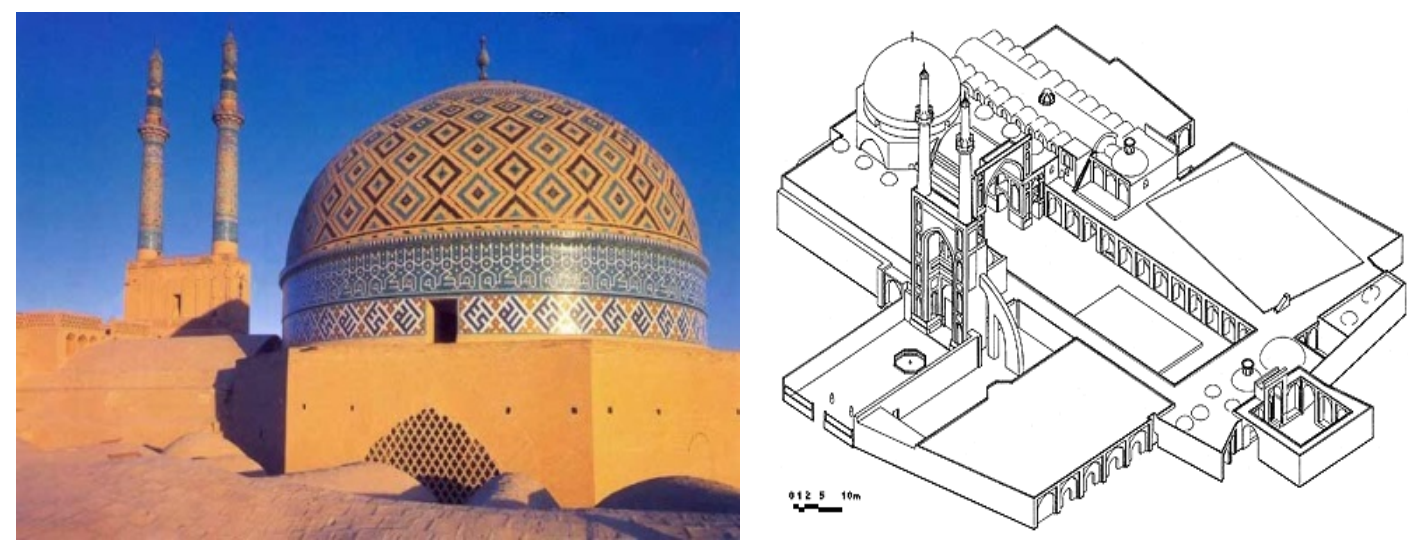

Figure 6. Jame Mosque of Yazd (Pirnia, 2001, 235)

\subsubsection{Vault, Dome, and Iwan}

Jame Mosque of Yazd was built in Khorasani style with a tint of columned Shabestan, which today nothing is left from that and instead, a columned Shabestan have been built at the east of its Miansara. The tholos and the Shabestans of south Miansara were built in Azerbaijani style. The tholoshas a discrete double-shell dome. The parietal, is a Nari dome and itself is a dome with light Shabdari hasp (Chefd), which for some reasons at the time of working, has been used as harsh Shabdari, and the inside of ribs is filled with KhanchePoosh style (Pirnia, 2001, 233-234).

\subsubsection{The Building Methods and Decorations}

The dome is decorated with a beautiful geometric thousand weaves design.The Mihrab has Moarragh tiles and has a Mogharnas vault at the top, which is inside a rectangular frame. The walls of tholoshas a surbase of light blue hexagonal tiles, which is located inside a narrow strip of Moarragh tiles. Various drawings of Moarragh tiles and pacanbe seen in the courtyard that probably most of them are new repairs. These decorations with floor 
bricks and the drawings of Moallaghi and inscriptions of Moarragh tiles and Kufic ones, have created an innovative and breathtaking collection that provokes admiration of the beholder (Golombek, 1995, 596).

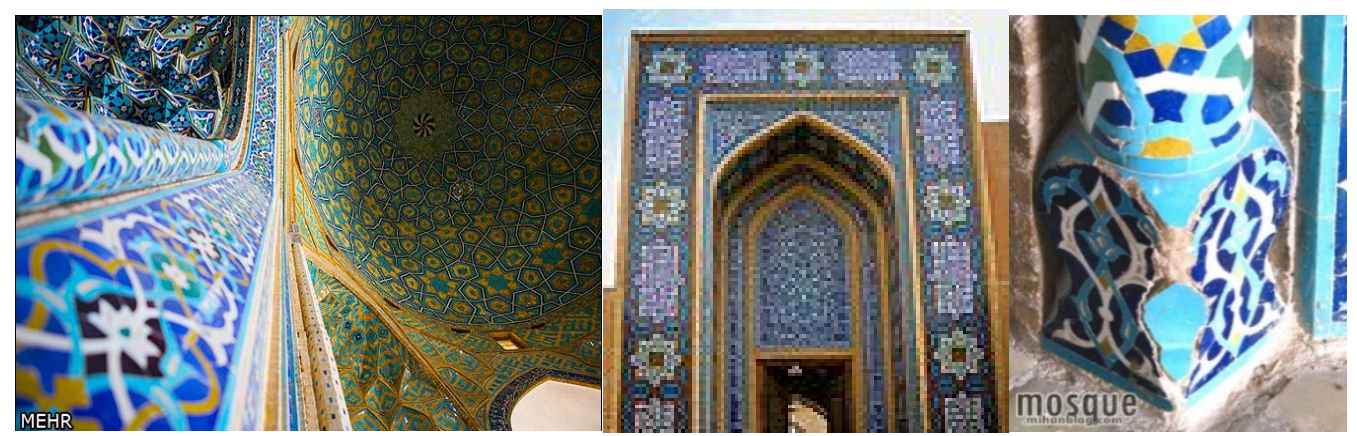

Figure 7. Jame Mosque of Yazd

\subsection{An Analysis of the Impact of Continent on the Designing and Formation of Physical Elements of the Mosques}

According tostudiesconducted and their results about the physical elements of the mosques as the operation of religious spaces in terms of continent and having appropriate conditions for the users, with its reasons and its adjustment with the continent of each area, we can mention the following.

\subsubsection{The Design of the Mosque in Cold and Mountainous Areas}

In cold and mountainous areas, the maximum use of heat and keeping it is the basis of any continental designing. Therefore, in order to set the environmental conditions and desired temperature to provide human comfort conditions, the following points can be considered. Building materials such as stone, brick, and clay which have high thermal mass, were used to build mosques. The materials, at the same time that are economic and available, stabilize the temperature inside the building and keep the heat of the day for the night. The ceiling of the most of the important mosques in the area are made of brick and with the form of dome or vault. Therefore these kind of ceilings have needed thick stone or brick bases which they also cause the increase of thermal mass and decrease of heat dissipation (Qobadian, 2003, 218). The height of the most of the mosques of this area is low and so maintaining the heat insideand heating indoors spaces can be done more easily due to less contact of the building with the outside environment.for the better. (The Blue Mosque of Tabriz) The size of the openings in the Shabestans of these kind of mosques are often small to prevent heat exchange with the outside environment and heat loss (Qobadian, 2003, 218).

The importance of yard in the other continents, is not seen here. Some of them are completely without a yard and some others which have a central yard, often does not have a strong central connection between the yard and the mosque's Shabestan. In the mosques that have a central courtyard, there are one or more wintery Shabestans which are fully enclosed and separate from the cold outer space. The plan of the mosques are mostly integrated with the surrounding context and is connected to the adjacent buildings, which this is effective in keeping heat inside the mosque as well as adjacent buildings. Generally these connected mosques have no central courtyard, and each asa fully enclosed unit with a voluminous body and relatively low height can be seen. The connection of these buildings to each other, in addition to creating an important religious center in the heart of Tabriz market, results in reducing the contact surface area of buildings with outside space and keeping heat inside the mosque. The joint yard of the mosques is as an enclosed space between them and does not have any central or physical relationship with any of the buildings surrounding it (Qobadian,2003, 219)

Some mosques in these areas despite having the central courtyard, the height of their tholos and its surrounding Shabestans is lower than Jame mosques and they have less opening houses and continentally these mosques at the cold seasons, provide more comfort for the worshipers. At some areas there is a certain type of mosque, which is much appropriate in terms of resistance to climatic factors. The mosques which are built in the heart of the mountain rock, one of the important factors for preventing coldness and cooling and providing the comfort conditions for worshipers in the mosque, is done in them. More than half of the body of the Shabestans is into the ground which has an important role to reduce heat exchange with the outside and also to increase thermal mass of the Shabestan. At the upper part of the south wall of this Shabestan a series of windows have been installed that in addition to providing light and ventilation, provides the possibility of sun shining in the winter 
and heating the inside space and the brick body of Shabestan (Qobadian, 2003, 227)

\subsubsection{Designing of the Mosque in Plateau Plains (Warm and Dry and Cold and Dry)}

Design and construction of mosques in the plains of Iran plateau, due to the exhausting heat and extreme cold in winter and also relatively large fluctuations in temperature during the day, should be done in a way that provide the spiritual and physical comfort conditions of man in the best way possible. Therefore, according to the changing environmental conditions during the day and in different seasons, the following general principles is observed in almost all mosques in these areas (Qobadian, 2003, 230). The most sensible physical characteristic of the mosques in Iran plateau plains, is the central courtyard. In these mosques, central courtyard protects the mosque space and its worshipers against the warm and dry environment of this region andthe pool and sprayed water in the floor of courtyard of the mosque, is effective in moderating the continental conditions inside the mosque. In the plains of the plateau, major materials for mosques had been clay and brick; albeit in case of access to stone, it was also used for the body of the mosque building and specially its bases. Because of the heavy weight of such materials and high thickness of the body of mosques, exterior walls and vaults of the mosque, in addition to providing thermal mass for the building, perform like a thick thermal insulation and prevent the heat exchange between the inside and outside of the building (Qobadian, 2003, 231). Due to the mosque's importance as the most important building of the city, as well as providing comfort conditions for worshipers in the summer, the height of mosques, especially their tholos had been high and most of them had been the tallest building in traditional cities of Iran. The body of tholos in these areas has more openings than the tholos in cold continents. Beside most important mosques in these areas, there is a wintery Shabestan with an enclosed space and relatively low height for performing religious ceremonies or speeches during the winter months. In some mosques, especially the mosques near the Iranian desert, there is a relatively small basement, like Jame Mosque of Yazd, and when the cold or the heat ismore than the toleration of the human being, this place will be used to pray (Qobadian, 2003, 231-232).

\subsection{Logic of Formation of Spaces and Physical Elements of Mosques against Climatic Factors in Geographical} Continents

\subsubsection{Dome}

Domical roofs due to their embossment,are constantly exposed to the wind and this is effective in loweringthe heat that the roof takes because of the intense shining of the sun. Also at night, the heat returns from the roof, is similarly removed rapidly. In Iran architecture, with the invention of double-shell domes which is used at Jame Mosque of Yazd and Goaharshad and also Blue Mosque of Tabriz, they have solved the question conditionally. In this way, the insulating of the space between two shells makes the inner shell colder than the outer shell. This method is more seen in architecture. Geometrically, the space of a hemisphere vault is almost three times as wide as its base. So the intensity of hot sun radiation on the round body is reduced. When the bottom of the domical vault comes to e lower temperature, and also because the domical body is exposed to the wind because of embossment, therefore the sunshine effects on that less than flat roof. The rounded roof is also good for outgoing heat radiation at night and preparing cooling at night, because it outgoes the heat that returns from the body of the building better (Tavassoli, 1974, 77).
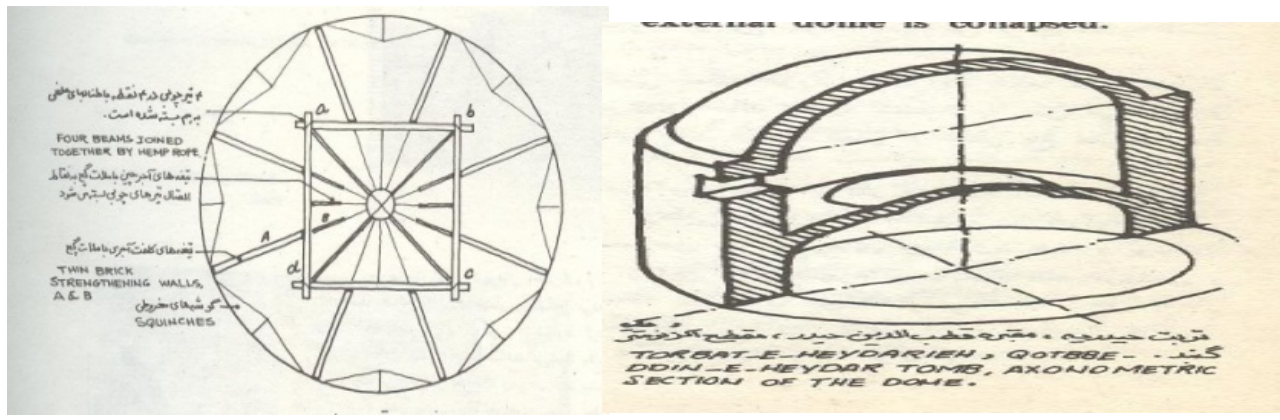

Figure 8. Double dome, the tomb of Ghotb od-din Heydar (Tavassoli, 1974, 80).

\subsubsection{Double Dome}

Space between the two shells, works as an insulator and causes the inner shell stays cooler than the outer shell that is heated by absorbing radiant heat. The inner shell binds the tholobate of the dome at the top, specially in 
tower tombs, and prevents from rupture of cylindrical tholobate, at the place of subsidence of the outer shell due to horizontal thrust pressure because of the weight of outer shell. The space below the dome will fit with the building of inner shell, while the outer shell will cause in the fitness of the building from outside (Tavassoli, 1974, 80).
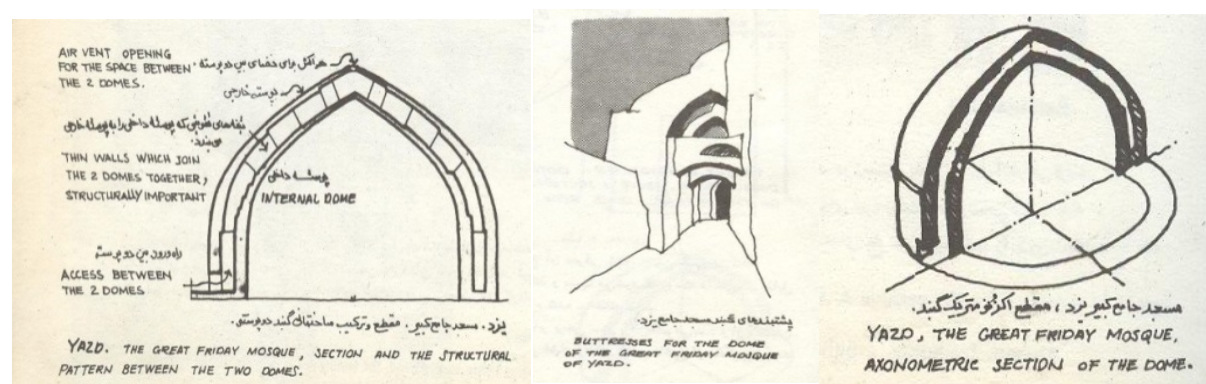

Figure 9. The big Jame Mosque of Yazd, section and the formation of buildings of double-shell dome (Tavassoli, 1974, 81)

\subsubsection{Vault}

Architects, have built a tubular structure at the thickness between vaulted ceiling and flat roof that usually became much, and so prevented from penetration of radiant heat inside, and the flat roof was a good opportunity to sleep at cool summer nights. Also in this way, the roof weighed less pressure on the walls. A hatch at the top of the dome does the ventilation and lightening. Through this hatch, the heat that the dome shell takes during the day and returns it at night into the dome, goes out quickly (Tavassoli, 1974, 80).
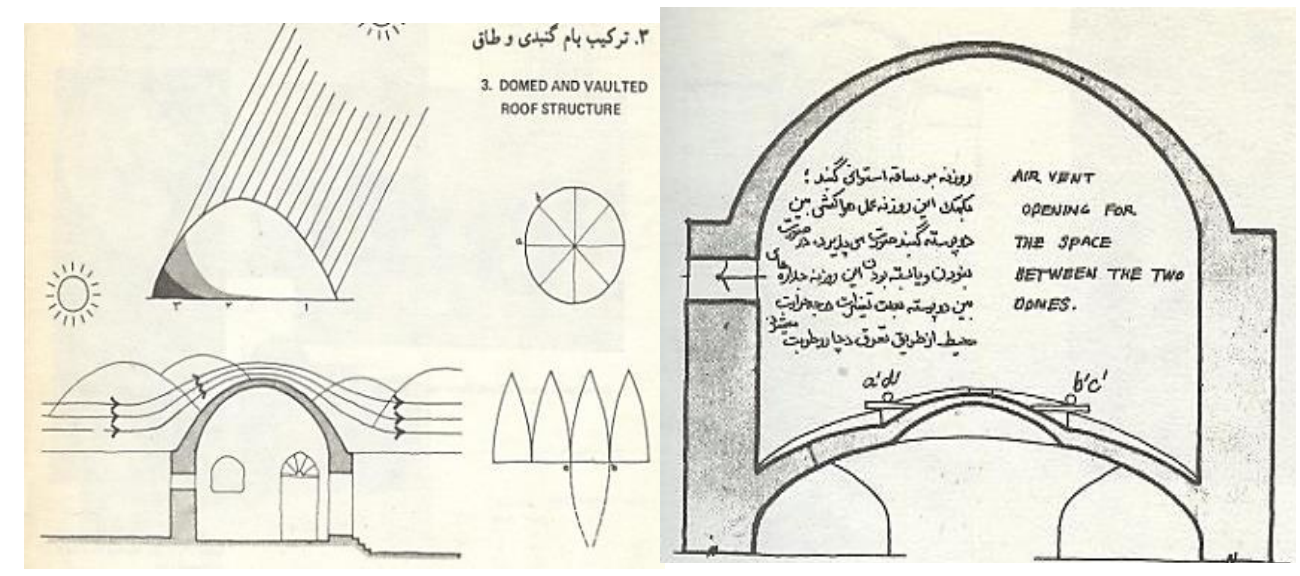

Figure 10.Combination of domical roof and vault (Tavassoli, 1974, 80)

\subsubsection{Central Courtyard}

In most continents of Iran, mosques are built with a central courtyard, but the courtyard of the mosques in plateau plains is relatively wider and more important. The most good looking and beautiful central courtyards, were built with a central symmetry towards the Mihrab and tholos, with four high Iwans along the axis of the central courtyard. Iwan, in terms of light, temperature, ventilation, and view is something between interior and exterior space, and often in warm seasons, when afternoon and evening, is the best place in terms of physical comfort. From the most beautiful four-Iwans mosquesGoharshadJame mosque could be mentioned (Qobadian, 2003, 234-235).

\subsubsection{Decorations}

Although the use of natural decorations has no effect on setting the environmental conditions inside the buildings, but decoration of the faces of religious buildings as inspired by flowers and plants and the sun and others, has an importance in themainly dry continent of Iran. It should be mentioned that Moarragh and seven-colored tiles of mosques in Iran, which mainly have a turquoise, azure, or blue background, symbolically promise freshness and prosperity in desert and arid cities of Iran. These tiled surfaces under the sun during the day and also during 
sunrise and sunset, create a very beautiful charm, in the brown background of the surrounding environment. The use of colored tiles in buildings on this wide scale and with this precision and transparency and durability of color and beauty of drawings, is just found in Iran and in the areas that were part of Iran in the past, or have been under the cultural influence of way of thinking and social traditions of Iran (Brand, 1998, 60)

\section{Conclusion}

Exaggeration about the role of geographical factors in the development of Islamic architecture is difficult. In a pleasant symmetry, the influential borders of Islam has been shown in some buildings of the Timurid period, which we have discussed. In considering the composition of mosque architecture in different continents, we can understand this important point that the weather factor have had a prominent role in giving a reasonable shape to the structure of the cities and the composition of physical architecture of the mosques in this area. Weather problems have always been posed for people of some areas specially warm and dry and cold and mountainous areas, as a big problem. These problems over thousands of years have led peopleto find solutions that astonishingly reduces annoying aspects of climate and uses its comforting aspects.It should be noted that the form of these three traditional mosques is designed based on the needs and climatic conditions of each region in such a way that the architecture of these mosques is inspired by the continental features. The use of traditional and indigenous materials shows the continental architecture principles of the region. Therefore the solutions that people of warm and dry areas around the world have found to respond to climatic problems, although are different in shape but have the same meaning. In the four different continents of Iran, the body of the mosque has been adapted to the climate of each region as much as possible, to provide the comforting needs of human inside the mosque (Tavassoli, 1974, 78).

According to studies carried out and their results, in the mosques' architecture of the Timurid period, the performance of religious buildings had been favorable and had provided good climatic conditions. Among the good reasons for mosques' architecture and finding the roots of some of structural and decorative elements and their adjustment to the climate of the given area, the following can be cited:

\begin{tabular}{|c|c|c|c|c|c|c|}
\hline Mosque & $\begin{array}{l}\text { Materials and } \\
\text { their thermal } \\
\text { mass }\end{array}$ & $\begin{array}{l}\text { Physical } \\
\text { elements of the } \\
\text { technique of } \\
\text { using the vault } \\
\text { and dome }\end{array}$ & $\begin{array}{l}\text { Openings' sizes } \\
\text { and central } \\
\text { courtyard and } \\
\text { Iwan }\end{array}$ & $\begin{array}{l}\text { Form and } \\
\text { structural side }\end{array}$ & decorations & others \\
\hline $\begin{array}{l}\text { The } \\
\text { Mosque } \\
\text { Tabriz }\end{array}$ & $\begin{array}{l}\text { Brick } \\
\text { materials- } \\
\text { high thermal } \\
\text { mass- thick } \\
\text { bases of the } \\
\text { building, } \\
\text { resulting in } \\
\text { continuance } \\
\text { of its life }\end{array}$ & $\begin{array}{l}\text { Double-shell } \\
\text { dome- creating } \\
\text { the comfort } \\
\text { conditions in } \\
\text { summer and } \\
\text { winter }\end{array}$ & $\begin{array}{l}\text { Completely } \\
\text { enclosed space } \\
\text { without any } \\
\text { Miansara and } \\
\text { yard- small } \\
\text { openings' sizes- } \\
\text { no Iwan }\end{array}$ & $\begin{array}{l}\text { Form of } \\
\text { placement } \\
\text { towards Mecca } \\
\text { side- } \\
\text { combination } \\
\text { of square and } \\
\text { round plan- } \\
\text { completely } \\
\text { extrovert }\end{array}$ & $\begin{array}{l}\text { In order to } \\
\text { maintain the } \\
\text { continuance of } \\
\text { the building in } \\
\text { coolness, use of } \\
\text { multicolored } \\
\text { tiles, turquoise, } \\
\text { azure, white } \\
\text { and black, and } \\
\text { golden }\end{array}$ & $\begin{array}{l}\text { Use of materials } \\
\text { of the region and } \\
\text { control of size of } \\
\text { the openings, and } \\
\text { use } \\
\text { completely } \\
\text { enclosed forms, } \\
\text { is recommended } \\
\text { in the region. }\end{array}$ \\
\hline $\begin{array}{l}\text { Cold and } \\
\text { mountainous } \\
\text { continent }\end{array}$ & \multicolumn{6}{|c|}{$\begin{array}{l}\text { High thermal mass of this building which is a continental advantage, is the result of thick bases for the tolerance } \\
\text { of heavy brick domes of the mosque. completely enclosed spaces and thick brick made body, is very appropriate } \\
\text { for cold and mountainous continent. The appropriate insulation for the ceiling and the floor is necessary. The } \\
\text { height of most of the mosques of this region is very low, therefore keeping the heat inside the building and } \\
\text { heating the indoor spaces, because of less contact surface with the outer environment, is done better. }\end{array}$} \\
\hline $\begin{array}{l}\text { GoharshadJame } \\
\text { Mosque }\end{array}$ & $\begin{array}{l}\text { Brick and } \\
\text { plaster } \\
\text { materials, } \\
\text { having high } \\
\text { thermal mass- } \\
\text { providing } \\
\text { good air }\end{array}$ & $\begin{array}{l}\text { Discrete } \\
\text { double-shell } \\
\text { dome, } \\
\text { providing } \\
\text { comfort } \\
\text { conditions in } \\
\text { summer and } \\
\text { winter- having } \\
\text { recess and }\end{array}$ & $\begin{array}{l}\text { Four Iwans that } \\
\text { are important } \\
\text { factors for } \\
\text { modulating } \\
\text { continental } \\
\text { conditions in } \\
\text { terms of light, } \\
\text { temperature, } \\
\text { ventilation and } \\
\text { view- having }\end{array}$ & $\begin{array}{l}\text { combination } \\
\text { of square and } \\
\text { round plan- } \\
\text { introvert and } \\
\text { having an } \\
\text { appropriate } \\
\text { side according } \\
\text { to Mecca side }\end{array}$ & $\begin{array}{l}\text { In order to } \\
\text { maintain the } \\
\text { continuance of } \\
\text { the building in } \\
\text { coolness, use of } \\
\text { multicolored } \\
\text { tiles, turquoise, } \\
\text { azure }\end{array}$ & $\begin{array}{l}\text { Introvert forms, } \\
\text { openings } \\
\text { appropriate to the } \\
\text { inner spaces- } \\
\text { introvert forms, } \\
\text { open and semi } \\
\text { open }\end{array}$ \\
\hline
\end{tabular}




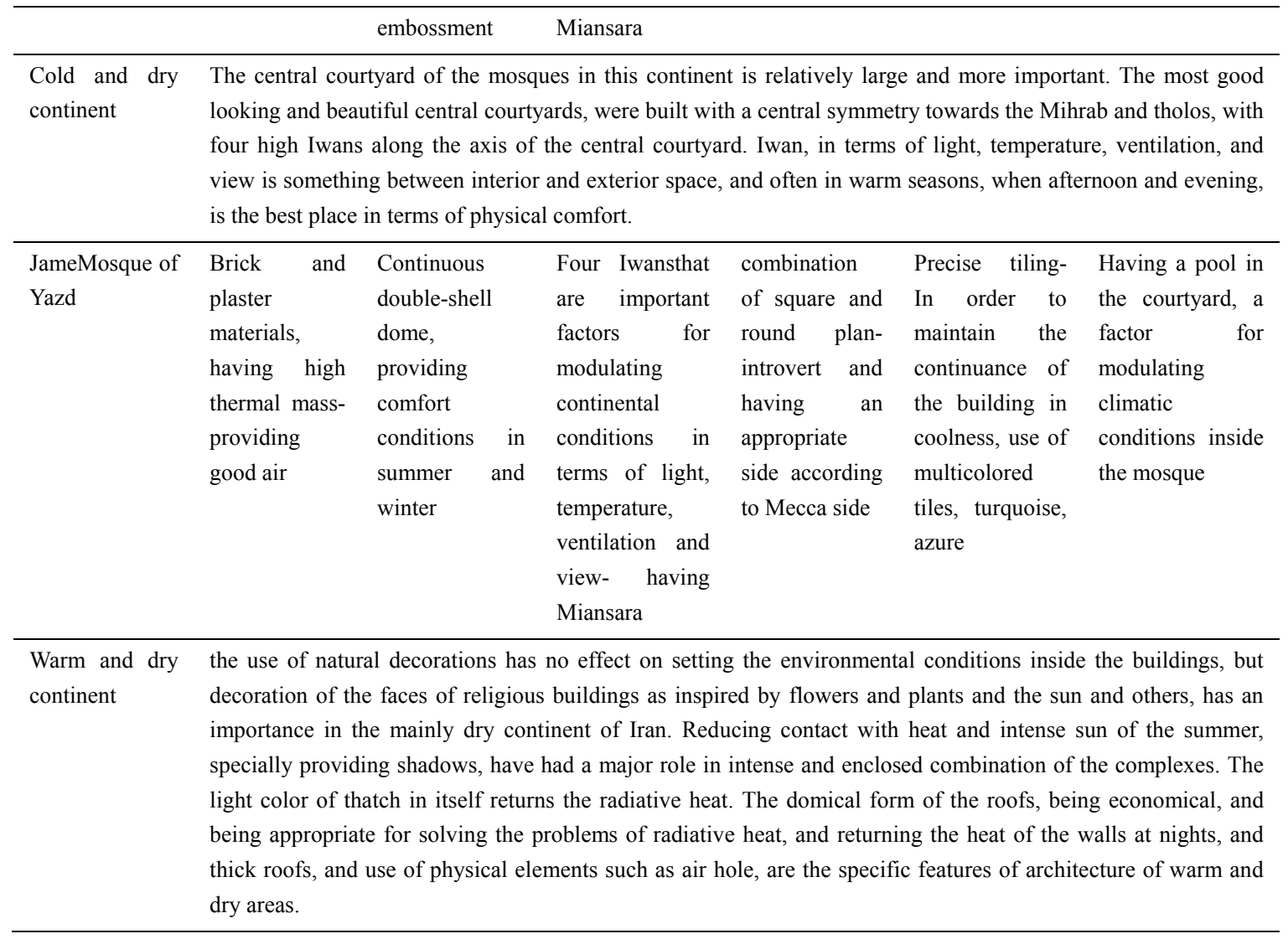

The main discussed area of architecture, is the form and shape of mosques in facing the continent, which is the result of its performance and role. Three parts of architecture, structure, and decorations are separately discussable and are from the important studies of this field. The method of building mosques according to performance, materials, the architect's scheme, and other factors, is different in each mosque and in the field of architectural research also various subjects such as scale, and proportions, and form, and their interrelations, decorations and inscriptions and other subjects are discussable. We hope this paper can open a way for various research subjects related to this masterpieces of Iran's architectural art.

The following diagram is the advised frame of the author about the different subjects in mosque's architecture which includes the areas discussed.

\section{Mosques of Timurid period}

Performance Form Continent

Religious architecture decorations structure sizes

Symbol design-materials-building combination of materials

Decorations- tiling and ... domestic materials

Techniques of use

Form symbolic drawings the meaning of decorations

Scale and appropriation

\section{References}

HillenBrand, R. (1998). Islamic architecture (form, performance and meaning), trans.Dr. IrajE’tesam, Tehran, 
Data processing and urban planning Co.

Memarian, G. H., \& Pirnia, K. (2001). The style of Iranian architecture, Tehran, Soroush Danesh press.

Pope, A. (1994). Architecture of Iran (wining of shape and color), trans.KeramatollahAfsar, Tehran, Farhangsara press, Yasavoli.

Pope, A. (1994). Architecture of Iran, trans.GholamHussein Sadri Afshar, Tehran, Farhangian press.

Qobadian, V. (2003). The continental study of the traditional buildings of Iran, Tehran, Tehran University Press.

ShalmaniAhmadi, M. H. (1985). Contemporary architecture of mosques, Tehran, Farhikhtegandaneshgah press.

Tavassoli, M. (1974). City building and architecture in warm and dry climates of Iran, Tehran, Department of Urban and Regional Planning, Faculty of Fine Arts, Tehran University.

Wilber, D. L. (1995). Timurid architecture in Iran and Turan, trans. Mohammad YusofKiani, Cultural Heritage.

\section{Copyrights}

Copyright for this article is retained by the author(s), with first publication rights granted to the journal.

This is an open-access article distributed under the terms and conditions of the Creative Commons Attribution license (http://creativecommons.org/licenses/by/3.0/). 